\title{
Inter-turn Short Circuit Stator Fault Identification for Induction Machines using Computational Intelligence Algorithms
}

\author{
S. A. Ethni, S. M. Gadoue and B. Zahawi \\ School of Electrical and Electronic Engineering, Newcastle University, Newcastle upon Tyne NE1 7RU, UK \\ Email: $\underline{\text { salaheddine.ethni@ncl.ac.uk }}$
}

\begin{abstract}
Under the umbrella of the Computational Intelligence (CI) the performance of a two algorithms: Particle swarm Optimization (PSO) and Bacterial Foraging Optimization (BFO), when used for inter-turn short circuit stator winding fault of induction machine, is investigated in this paper. The proposed condition monitoring technique uses time domain terminal data in conjunction with the optimization algorithm and an induction machine model to indicate the presence of a fault and provide information about its nature and location. The proposed technique is evaluated using experimental data obtained from a $1.5 \mathrm{~kW}$ wound rotor three-phase induction machine. PSO and BFO are shown to be effective in identifying the type and location of the fault without the need for prior knowledge of various fault signatures.
\end{abstract}

Index Terms-- Induction machine, computational intelligence, condition monitoring.

\section{INTRODUCTION}

Induction motors are the most widely used form of electric machines due to their reliability and simplicity of construction. The condition monitoring of the motor is essential to detect any developing fault at an early stage, reducing the risks of severe motor faults. Faults can then be treated before completely damaging the motor, thus decreasing the maintenance cost and shutdown time. Therefore, there is an increasing need for a simple and reliable technique to detect incipient motor faults. Traditional induction machine condition monitoring techniques [1] usually involve the use of sensors embedded in the machine to measure, for example, temperature or vibration [2]. There has also been considerable interest in detecting windings and other machine faults by examination of terminal current waveforms [3] using data gathered under steady-state operating condition. This may involve the calculation of quantities such as input power [4] or negative sequence components [5]. Recent trends in condition monitoring include the detection of machine faults using data acquired during speed transients [6] and the estimation of machine parameters [7-11]. Winding faults such as turn-to-turn, phaseto-phase, coil-to-coil and coil-to-ground faults are examples of electrical faults in IM. In squirrel cage rotor machines, bars crack and bad connections with the end rings can also occur. Furthermore, short circuit of rotor laminations is a common fault in both squirrel cage and wound rotor machines. Stator faults of IM are some of the most commonly reported faults with $38 \%$ of all reported faults being related to stator $[18,17$, 16]. Stator inter-turn faults are one of the more prevalent and potentially destructive in IM, these faults start as small shorts between a few turns in the same winding producing high current which causes severe localized heating and the fault rapidly spreads to a larger part of the winding leading to further progressive degradation that may mature into a more severe turn-to-ground fault. Failure of the insulation between winding and ground can cause a large ground current, which potentially can damage the core of the machine permanently. The stator is subjected to various stresses due to high temperature, movement of laminations and coils. These factors usually lead to insulation failure, which eventually produce different types of stator faults. Conventional stator insulation failure protection in an industrial environment is by ground fault relays and negative-sequence or phase current balance relays. However, with unbalanced line voltages negative-sequence relays would cause nuisance trips. Ground fault relays would not be effective for early fault detection purposes $[19,20]$.

A new fault identification technique using machine terminal data and rotor position information has been recently proposed by the authors [8-10]. In this method, a computational intelligence search algorithm is implemented to estimate the values of machine parameters which give the best possible match between the performance of the faulty experimental machine and its mathematical model, thus identifying both the location and nature of the winding fault. Figure 1 shows a schematic diagram of the fault identification technique.

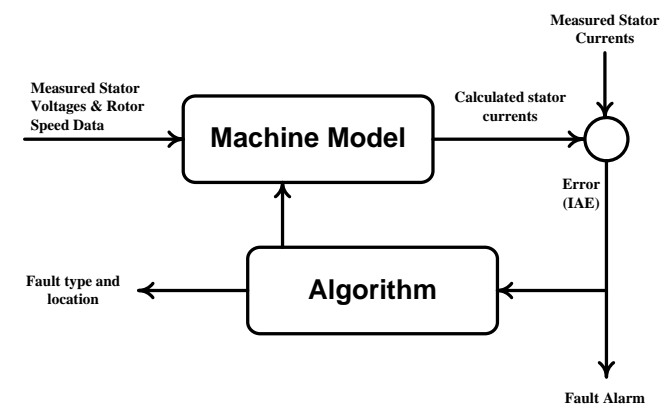

Fig. 1 Block diagram of the stochastic search based fault identification technique 
Stator currents are calculated from an induction motor dynamic model and compared to the actual measured currents to produce a set of current errors that are integrated then summed to give an overall error function. When the machine is in its healthy state, there is a high correlation between its effective parameters and the model parameters resulting in a small calculation error. If a fault develops in the machine, its electrical parameters are of course modified and when the measured currents are compared with calculated currents there will be a large calculation error giving a fast indication that a fault of some type is present. Fault identification is carried out by continuously adjusting the induction machine model parameters off-line, using a stochastic search method, to achieve the minimum error between the measured and calculated stator currents. The new set of model parameters then defines the nature and location of the fault. In this paper two stochastic optimization techniques will be used and compared, Particle Swarm Optimization (PSO) and Bacterial Foraging Optimization (BFO). Unlike many other methods, it should be noted here that the new stochastic search based approach does not require any expert prior knowledge of the type of fault or its location; both are identified as an integral part of the optimisation process.

Experimental tests based on a $1.5 \mathrm{~kW}$ wound rotor three phase induction machine have been carried out to validate the proposed fault identification algorithm with stator and rotor faults considered. Results confirm the capability of PSO and BFO to identify and locate the fault without the need for a previous knowledge of different fault current signatures.

\section{Induction Machine Mathematical Model}

The mathematical ABCabc model of an induction motor is developed using Simulink software and used with PSO and BFO to identify inter-turn short circuit winding faults. This $\mathrm{ABCabc}$ model is obtained from the standard machine voltage equations and represented by (1):

$$
\left[\begin{array}{c}
V_{s A} \\
V_{s B} \\
V_{s C} \\
V_{r a} \\
V_{r b} \\
V_{r c}
\end{array}\right]=\left[\begin{array}{cccccc}
R_{s A}+p L_{s s} & p M_{s s} & p M_{s s} & p M_{s r} \cos \theta_{r} & p M_{s r} \cos \theta_{r 1} & p M_{s r} \cos \theta_{r 2} \\
p M_{s s} & R_{s B}+p L_{s s} & p M_{s s} & p M_{s r} \cos \theta_{r 2} & p M_{s r} \cos \theta_{r} & p M_{s r} \cos \theta_{r 1} \\
p M_{s s} & p M_{s s} & R_{s C}+p L_{s s} & p M_{s r} \cos \theta_{r 1} & p M_{s r} \cos \theta_{r 2} & p M_{s r} \cos \theta_{r} \\
p M_{s r} \cos \theta_{r} & p M_{s r} \cos \theta_{r 2} & p M_{s r} \cos \theta_{r 1} & R_{r a}+p L_{r r} & p M_{r r} & p M_{r r} \\
p M_{s r} \cos \theta_{r 1} & p M_{s r} \cos \theta_{r} & p M_{s r} \cos \theta_{r 2} & p M_{r r} & R_{r b}+p L_{r r} & p M_{r r} \\
p M_{s r} \cos \theta_{r 2} & p M_{s r} \cos \theta_{r 1} & p M_{s r} \cos \theta_{r} & p M_{r r} & p M_{r r} & R_{r c}+p L_{r r}
\end{array}\right] \cdot\left[\begin{array}{c}
I_{s A} \\
I_{s B} \\
I_{s C} \\
I_{r a} \\
I_{r b} \\
I_{r c}
\end{array}\right](1)
$$

where $\left(V_{s A}, V_{s B}, V_{S C}\right),\left(I_{s A}, I_{s B}, I_{S C}\right)$ are the stator winding voltages and currents, $\left(V_{r a}, V_{r b}, V_{r c}\right),\left(I_{r a}, I_{r b}, I_{r c}\right)$ are the rotor winding voltages and currents, $\left(R_{s A}, R_{s B}, R_{s C}\right),\left(R_{r a}, R_{r b}, R_{r c}\right)$ are the stator and rotor winding resistances respectively, $L_{s s}$ and $L_{r r}$ are the stator and rotor winding self-inductances respectively, $M_{s s}$ and $M_{r r}$ are the mutual inductance between pairs of stator and rotor windings respectively, $M_{s r}$ is the peak value of the rotor position dependent mutual inductance between stator and rotor winding pairs, $\theta_{r}$ is the rotor position angle, $\theta_{r l}=\theta_{r}+2 \pi 3, \theta_{r 2}=\theta_{r}+4 \pi 3$ and $p$ is the differential operator.

\section{Particle Swarm Optimization}

Particle Swarm Optimisation (PSO) is an iterative optimisation technique inspired by the biological behaviour of a swarm of birds or bees [14]. Unlike evolutionary optimization techniques such as Genetic Algorithms, it is not based on the idea of the survival of the fittest. Instead, it is a collective method in which members of the population cooperate to find a global optimum in a partially random way and without any selection. Members of the population with the lower fitness functions are not discarded but do survive and can potentially be the future successful members of the swarm, this technique has been explained in more details by the authors in previous papers [8, 9].

\section{BACTERIAL FORAGING OPTIMIZATION}

Bacterial Foraging Optimization (BFO) was introduced in 2002 by Passino [13]. The BFO is a stochastic search and optimization technique based on the foraging behaviour of Escherichia coli (E. coli) bacteria which takes advantage of a variety of bacterial swarming and social foraging behaviours. Unlike PSO the bacterial foraging is based on the idea of the survival of the fittest. In contrast, PSO is a collective method in which members of the population work together to find a global optimum or near optimum to a degree of random way and without any selection. BFO algorithm has been applied previously by the authors using the same technique for IM stator and rotor winding fault identification in [10].

\section{EXPERIMENTAL RESULTS}

The experimental work was conducted on a $1.5 \mathrm{~kW}, 50 \mathrm{~Hz}$, $240 \mathrm{~V}$, 2-pole wound rotor induction machine coupled to a $3 \mathrm{~kW}$ DC machine used as a generator to provide the necessary load torque. The induction motor has a star connected stator windings and a short circuited delta connected rotor winding. Standard tests (dc, no-load and locked rotor tests) [15] were carried out to determine the nominal values of the machine parameters, giving the following results in Table 1 . Tests are carried out emulating stator inter-turn winding fault condition. In this test, the measured waveforms are the three terminal voltages, three stator currents and rotor speed. Voltage differential probes, current probe amplifier and a digital tachometer are used to measure these signals. Data are collected over a time window of $0.1 \mathrm{sec}$, with a sampling interval of $1 \mathrm{~ms}$. For this test, data was gathered from a loaded machine (applied load of 0.55 $\mathrm{kW}$ ) operating at a steady-state. It was not possible to obtain convergence when using the steady-state no-load test data or transient test data. The acquired data were then processed offline using PSO and BFO algorithms to determine the effective parameters of the machine. The position of each particle/bacterium within the solution space $\mathbf{X}_{i}=\left(R_{S A}, R_{S B}\right.$, $R_{S C}, L_{S A}, L_{S B}, L_{S} C, M_{A B}, M_{B C}, M_{C A}$ ) is a potential solution which can be applied to the induction motor model to evaluate a set of stator currents. Each parameter value must lie within a predefined search space and the overall calculation error; the Integral Absolute Error (IAE) as defined in (2). This error 
function is the cost function to be minimized by the algorithms.

$$
I A E=\sum\left(\left|i_{s A m}-i_{s A c}\right|+\left|i_{s B m}-i_{s B c}\right|+\left|i_{s C m}-i_{s C c}\right|\right) \Delta T
$$

where $\left(i_{s A m}, i_{s B m}, i_{s C m}\right)$ are the measured currents, $\left(i_{s A c}, i_{s B c}, i_{s C c}\right)$ are the calculated currents and $\Delta T$ is the sampling period.

TABLE 1

INDUCTION MOTOR PARAMETERS

\begin{tabular}{|c|l|}
\hline INDUCT ION MOT OR PARAMETERS & Values \\
\hline Stator resistances & $R_{s}=5.88 \Omega$ \\
\hline Rotor resistances & $R_{r}=6.83 \Omega$ \\
\hline Stator self-inductances & $L_{s s}=0.729 \mathrm{H}$ \\
\hline $\begin{array}{c}\text { Rotor self-inductances } \\
\text { Mutual inductances between the stator } \\
\text { windings }\end{array}$ & $L_{r r}=0.578 \mathrm{H}$ \\
\hline $\begin{array}{c}\text { Mutual inductances between the rotor } \\
\text { windings }\end{array}$ & $M_{r r}=0.7 \mathrm{H}$ \\
\hline $\begin{array}{c}\text { Mutual inductance between stator and } \\
\text { rotor winding pairs }\end{array}$ & $\begin{array}{l}M_{s r}=0.769 \mathrm{H} \\
M_{r s=}\end{array}$ \\
\hline
\end{tabular}

\section{A. Stator winding inter-turn fault}

A developing stator inter-turn winding fault is emulated by short circuiting part of one stator phase winding (winding A) as shown in Fig. 2.

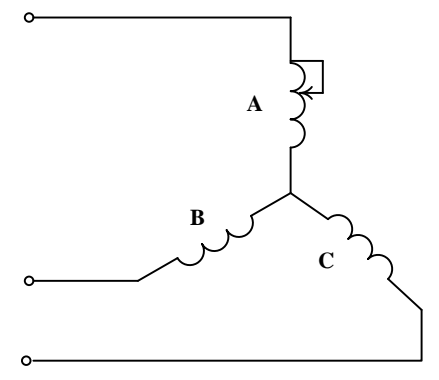

Fig. 2 developing stator winding inter-turn short circuit fault test circuit

Asymmetrical inter-turn short circuit in stator windings is a type of fault which is common in induction motors. Normally, short-circuits in stator windings occur between turns of one phase, or between turns of two phases. In this case, winding A was partially short circuited by connecting a link across two adjacent stator winding terminals. The presence of the shortcircuit fault will have a substantial impact on the stator self and mutual inductances as well as the stator resistance values. A total of nine parameters, $\mathbf{X}_{\mathrm{i}}=\left(R_{S A}, R_{S B}, R_{S C}, L_{S A}, L_{S B}, L_{S C}\right.$, $\left.M_{A B}, M_{B C}, M_{C A}\right)$, were found to be necessary in order to obtain convergence, with the other parameters kept constant at the nominal values identified in previous work [8-11]. The search space for the motor parameters was set as follows: $1 \leq \mathrm{R}_{\mathrm{S}} \leq$ $25,1 \leq \mathrm{R}_{\mathrm{r}} \leq 25,0.05 \leq \mathrm{M}_{\mathrm{ss}} \leq 2.5,0.05 \leq \mathrm{M}_{\mathrm{rr}} \leq 2.5,0.1 \leq \mathrm{L}_{\mathrm{rr}} \leq$
1.5 and $0.1 \leq \mathrm{L}_{\mathrm{ss}} \leq 1.5$. To make sure that the absence of rotor parameters from the optimisation process did not have any significant effect on the search result, a second investigation was carried out using rotor parameters $\mathbf{X}_{\mathrm{i}}=\left(\mathrm{R}_{\mathrm{ra}}, \mathrm{R}_{\mathrm{rb}}, \mathrm{R}_{\mathrm{rc}}, \mathrm{L}_{\mathrm{ra}}\right.$, $\mathrm{L}_{\mathrm{rb}}, \mathrm{L}_{\mathrm{rc}}, \mathrm{M}_{\mathrm{ab}}, \mathrm{M}_{\mathrm{bc}}, \mathrm{M}_{\mathrm{ca}}$ ) as variables, maintaining all other parameters at the nominal values.

\section{B. Stator inter-turn winding fault identification using PSO}

The PSO algorithm is implemented to identify the presence of a developing stator winding inter-turn fault based on the experimental measurements. In this test values of $c_{1}=0.5$ and $c_{\max }=1$ were used, together with a total swarm population of 8 particles ( 8 particles with nine dimensions for each particles). Fig. 3 and Fig. 4 show the estimated stator resistances and self-inductances, respectively. The error function corresponding to the existing best solution is shown in Fig. 5. In this test the final estimated values of the stator resistances and self-inductances are given in Table 2 .

\section{TABLE 2}

FINAL VALUES OF ST ATOR WINDING PARAMETERS OBT AINED USING PSO WITH ST ATOR INTER-TURN FAULT

\begin{tabular}{|c|c|c|c|c|c|}
\hline$R_{s A}(\Omega)$ & $R_{s B}(\Omega)$ & $R_{s C}(\Omega)$ & $L_{s A}(H)$ & $L_{s B}(H)$ & $L_{s C}(H)$ \\
\hline 2.4625 & 6.3847 & 6.5171 & 0.200603 & 0.46547 & 0.411652 \\
\hline
\end{tabular}

The PSO algorithm successfully identifies the presence of the stator inter-turn winding fault as indicated by the low value of $\mathrm{R}_{\mathrm{SA}}$ compared with $\mathrm{R}_{\mathrm{SB}}$ and $\mathrm{R}_{\mathrm{SC}}$ and the low value of $\mathrm{L}_{\mathrm{SA}}$ compared with $\mathrm{L}_{\mathrm{sB}}$ and $\mathrm{L}_{\mathrm{SC}}$ and $\mathrm{M}_{\mathrm{AB}}=0.701989 \mathrm{H}, \mathrm{M}_{\mathrm{BC}}=$ $0.793266 \mathrm{H}, \mathrm{M}_{\mathrm{CA}}=0.65742 \mathrm{H}$ (compared with a nominal value of $0.25151 \mathrm{H}$ ). Fig. 6 shows the measured stator currents $\left(i_{s A m}, i_{s B m}, i_{s C m}\right)$ and the currents $\left(i_{s A c}, i_{s B c}, i_{s C c}\right)$ calculated using the final parameter values obtained by the PSO algorithm showing good agreement between the two current waveforms. The number of iterations required to obtain convergence of the data sets (stator resistance, self and mutual inductances) was 1560 . The calculation error falls from a maximum value of 0.798721 A.s to 0.12 A.s. The second investigation to optimize the rotor parameters identified that the rotor parameters are approximately at the same value, close to their nominal values identified in [8-11], confirming that rotor parameters are not affected by the presence of the stator fault.

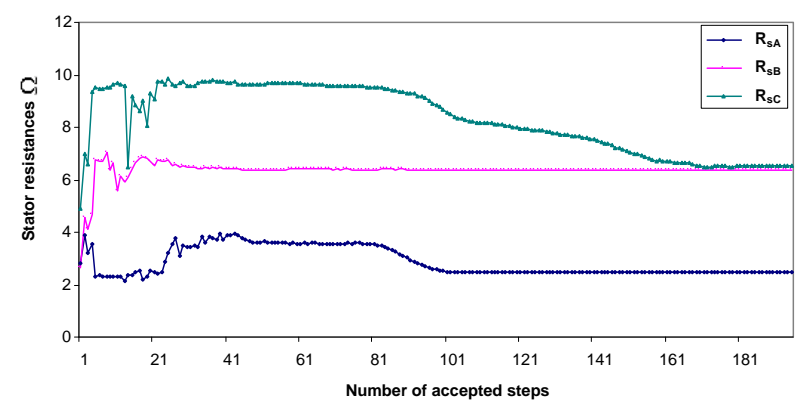

Fig.3 Estimated stator resistances obtained by PSO with a stator inter-turn short circuit fault; steady state load conditions 


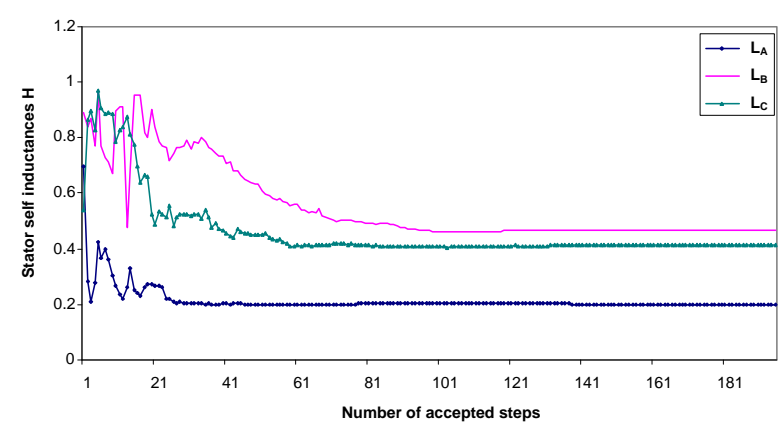

Fig. 4 Estimated stator self-inductances obtained by PSO with a stator interturn short circuit fault; steady state load conditions

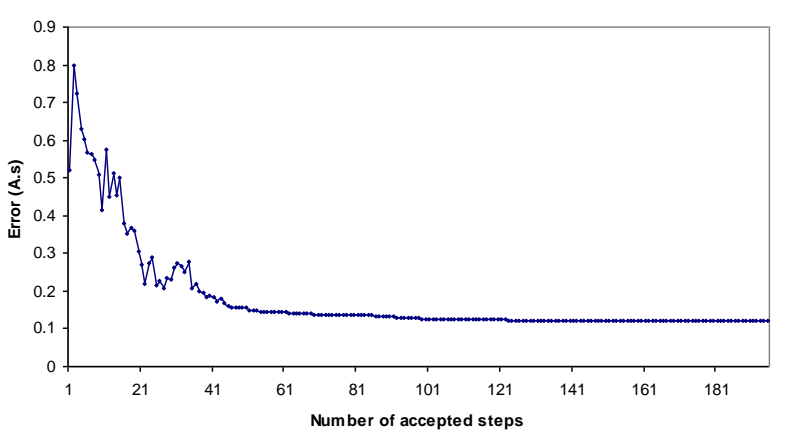

Fig. 5 Current error using the estimated parameters obtained by PSO with stator inter-turn short circuit fault; steady state load conditions

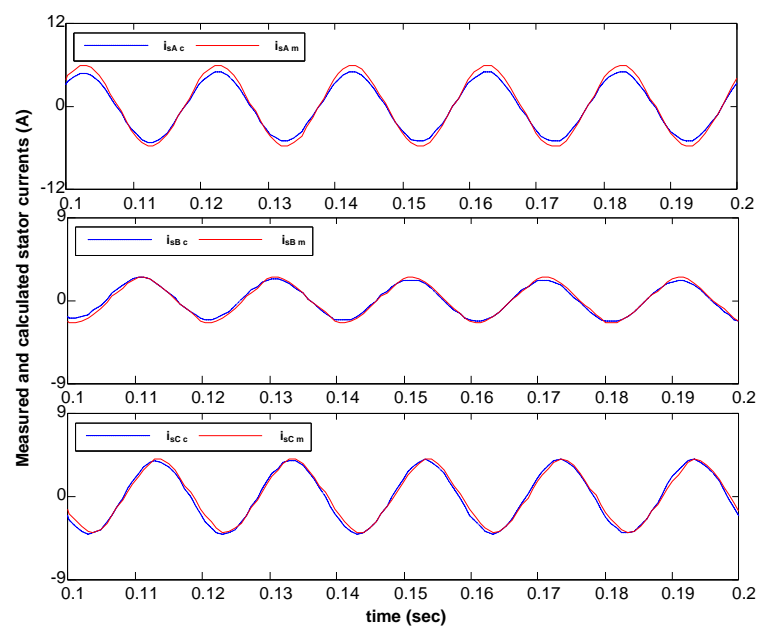

Fig. 6 Measured $\left(i_{s A m}, i_{s B m}, i_{s C m}\right)$ and calculated $\left(i_{s A c}, i_{s B c}, i_{s C c}\right)$ stator current waveforms using the estimated parameters obtained by PSO with a stator inter-turn short circuit fault; steady state load conditions

\section{Stator inter-turn winding fault identification using BFO}

A process similar to that used with PSO will be implemented with the BFO for stator inter-turn short-circuits winding fault identification. As mentioned earlier it was necessary to introduce self and mutual inductances as variable parameters in the search process. The many trial runs carried out identified resistances and self and mutual inductances of a stator to be the most appropriate parameters combination to be used.

The BFO parameters necessary for its implementation are first specified including the number of bacteria within the population $(S=8)$, the initial position of each bacterium within the solution space, the number of chemotactic steps $\left(\mathrm{N}_{\mathrm{c}}=10\right)$ taken during each bacterium lifetime, the maximum number of successive steps in any one swim sequence $\mathrm{N}_{\mathrm{s}}=4$ steps and the number of reproduction $\left(\mathrm{N}_{\mathrm{re}}=4\right)$ and elimination/ dispersal events $\left(\mathrm{N}_{\mathrm{ed}}=2\right)$ that would occur during the BFO implementation. Fig. 7 and Fig. 8 show the BFO estimated stator resistances and self-inductances, respectively. The error function corresponding to the existing best solution is shown in Fig. 9. The stator resistances and self-inductances were estimated at the end of the optimization process are given in Table 3 .

TABLE 3

FINAL VALUES OF ST ATOR WINDING PARAMETERS OBT AINED USING BFO WITH ST ATOR INTER-TURN FAULT

\begin{tabular}{|l|c|c|c|c|c|}
\hline$R_{s A}(\Omega)$ & $R_{s B}(\Omega)$ & $R_{s C}(\Omega)$ & $L_{S A}(H)$ & $L_{s B}(H)$ & $L_{s C}(H)$ \\
\hline 4.4509 & 6.7316 & 6.50516 & 0.27264 & 0.57354 & 0.47457 \\
\hline
\end{tabular}

excluding the computational time out of consideration the BFO algorithm successfully identifies the presence of the stator short-circuit winding fault as indicated by the low value of $R_{\mathrm{SA}}$ compared with $\mathrm{R}_{\mathrm{SB}}$ and $\mathrm{R}_{\mathrm{SC}}$ and the low value of $\mathrm{L}_{\mathrm{SA}}$ compared with $\mathrm{L}_{\mathrm{sB}}$ and $\mathrm{L}_{\mathrm{SC}}$ and $\mathrm{M}_{\mathrm{AB}}=0.62103 \mathrm{H}, \mathrm{M}_{\mathrm{BC}}=$ $0.736786 \mathrm{H}, \mathrm{M}_{\mathrm{CA}}=0.615039 \mathrm{H}$ (compared with a nominal value of $0.25151 \mathrm{H}$ ). Fig.10 shows the measured stator currents $\left(i_{s A m}, i_{s B m}, i_{S C m}\right)$ and the currents $\left(i_{s A c}, i_{S B c}, i_{S C c}\right)$ calculated using the final parameter values obtained by the BFO algorithm showing good agreement between the two current waveforms.

The number of investigations required to obtain convergence of the data sets (stator resistances and self and mutual inductances) was 1996. The calculation error falls from a maximum value of 0.753 A.s to 0.17123 A.s. The same code was used to investigate the rotor parameters verified that the rotor parameters are approximately at the same value, close to their nominal values, confirming that rotor parameters are not affected by the presence of the stator fault.

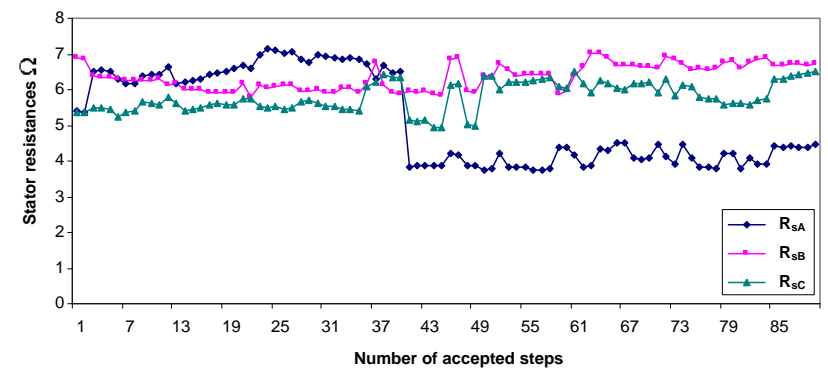

Fig. 7 Estimated stator resistances obtained by BFO with inter-turn stator short circuit fault; steady state load conditions 


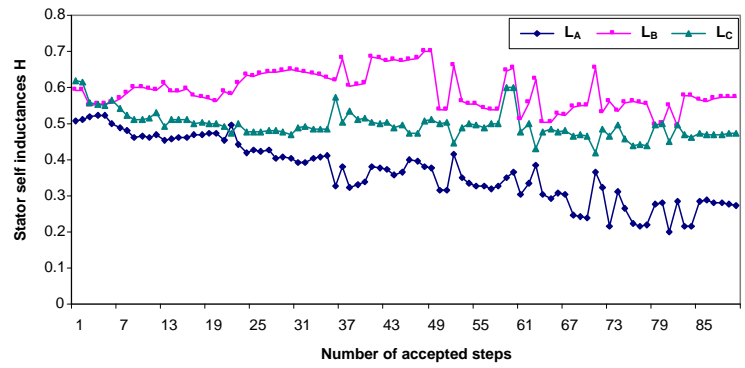

Fig. 8 Estimated stator self-inductances obtained by BFO with a stator interturn short circuit fault; steady state load conditions

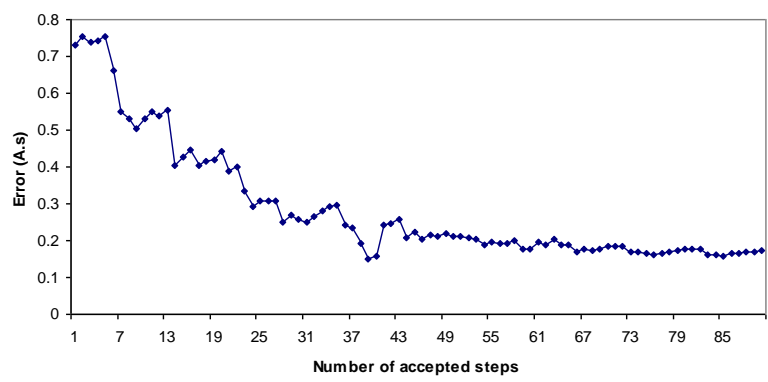

Fig. 9 Current error using the estimated parameters obtained by BFO with a stator inter-turn short circuit fault; steady state load conditions

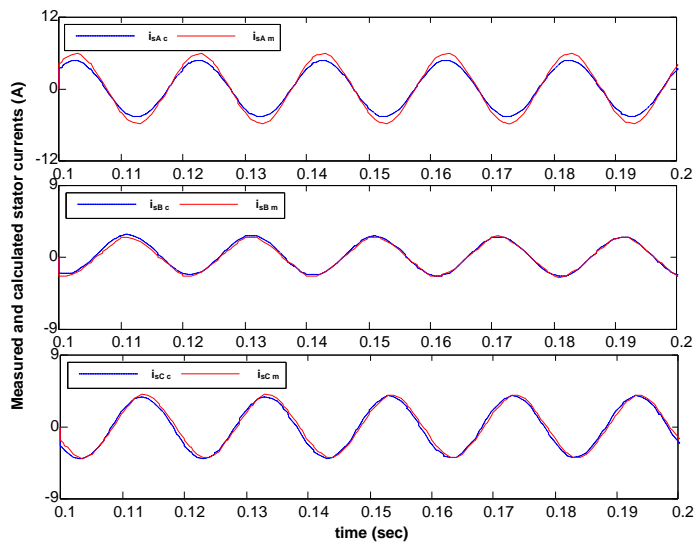

Fig. 10 Measured $\left(i_{s A m}, i_{s B m}, i_{s C m}\right)$ and calculated $\left(i_{s A c}, i_{s B c}, i_{s C c}\right)$ stator current waveforms using the estimated parameters obtained by BFO with a stator inter-turn short circuit fault; steady state load conditions

\section{Comparison between PSO and BFO algorithms}

Due to the fact that including self-inductances in the search process will potentially increase the sensitivity of the cost function consequently more attention has to be taken to confine the search space to prevent particles/bacterium leaving the search space all together which will prevent currents to go to infinity. Table 4 shows a comparison of the PSO results with those obtained using the BFO algorithm. The PSO algorithm had a success rate of about $75 \%$ when used with the load measured current data compared with a success rate of about $60 \%$ for the BFO algorithm. PSO was also substantially faster than $\mathrm{BFO}$ which requires a much larger number of investigations to produce consistent values for the estimated stator resistances (the number of investigations when conducting a BFO search being noticeably larger than the number of accepted solutions). This demonstrates the robust nature of the PSO process and its suitability to this type of nonlinear multivariable optimization problem. Both algorithms showed estimated stator and rotor parameters to converge to similar values, confirming that there is fault in the machine's stator windings.

TABLE 4

ALGORITHM COMPARISIONS; ST ATOR SHORT-CIRCUIT WINDING FAULTS

\begin{tabular}{|c|c|c|c|c|}
\hline \multicolumn{5}{|c|}{ Stator fault } \\
\hline Algorithm & $\begin{array}{c}\text { Computational } \\
\text { time (sec) }\end{array}$ & $\begin{array}{c}\text { Current } \\
\text { error } \\
\text { (A) }\end{array}$ & $\begin{array}{c}\text { Number of } \\
\text { evaluations }\end{array}$ & $\begin{array}{c}\text { Success } \\
\text { Rate }\end{array}$ \\
\hline PSO & 156 & 0.12 & 1560 & $\begin{array}{c}75 \%(120 \\
\text { trials }\end{array}$ \\
\hline BFO & 199.6 & 0.17133 & 1996 & $\begin{array}{c}60 \%(120 \\
\text { trials })\end{array}$ \\
\hline Algorithm & $\begin{array}{c}\text { Computational } \\
\text { time (sec) }\end{array}$ & $\begin{array}{c}\text { Current } \\
\text { error } \\
\text { (A) }\end{array}$ & $\begin{array}{c}\text { Number of } \\
\text { evaluations }\end{array}$ & $\begin{array}{c}\text { Success } \\
\text { Rate }\end{array}$ \\
\hline PSO & 28 & 0.5415 & 280 & $\begin{array}{c}70 \%(120 \\
\text { trials })\end{array}$ \\
\hline BFO & 167.7 & 0.8358 & 1677 & $\begin{array}{c}60 \%(120 \\
\text { trials })\end{array}$ \\
\hline
\end{tabular}

\section{CONCLUSION}

The use of two computational intelligence algorithms (PSO and $\mathrm{BFO}$ ) to detect a developing induction motor stator winding fault has been presented in this paper. The condition monitoring method is based on the comparison of measured machine stator currents with those obtained from a machine mathematical model, and then using the algorithms to minimise the resulting error function. The two algorithms have been shown to be effective in determining the winding fault type and location. However results show that the PSO algorithm is better suited for this type of application, achieving a success rate of about $70 \%$ compared with $60 \%$ for $\mathrm{BFO}$ algorithm with noticeably improved execution times because of the smaller number of function evaluations needed for convergence.

\section{REFERENCES}

[1] P. J. Tavner, and J. Penman, "Condition monitoring of electrical machines,” Research Studies Press, 1987, Letchworth, England, 1987.

[2] P. Zhang, Y. Du, T. G. Habetler, and B. Lu, "A Survey of Condition Monitoring and Protection Methods for Medium-Voltage Induction Motors," IEEE Transactions on Industry Applications, vol. 47, no. 1, pp. 34-46, Jan-Feb 2011. 
[3] M. E. H. Benbouzid. "A review of induction motors signature analys is as a medium for faults detection", IEEE Transactions on Industrial Electronics, vol. 47, no.5, pp. 984-992, 2000.

[4] A. J. Trzynadlowski, and E. Ritchie. "Comparative investigation of diagnostic media for induction motors: a case of rotor cage faults", IEEE Transactions on Industrial Electronics, vol. 47, no.5, pp. 10921099, 2000.

[5] F. C. Trutt, J. Sottile, and J. L. Kohler. "Online condition monitoring of induction motors", IEEE Transactions on Industry Applications, vol. 38, no.6, pp. 1627-1632, 2002.

[6] H. Douglas, P. Pillay, A. K. Ziarani. "Broken rotor bar detection in induction machines with transient operating speeds", IEEE Transactions on Energy Conversion, vol. 20, no.1, pp. 135-141, 2005.

[7] M. S. N. Said, M. E. H. Benbouzid, and A. Benchaib. "Detection of broken bars in induction motors using an extended Kalman filter for rotor resistance sensorless estimation”, IEEE Transactions on Energy Conversion, vol. 15, no.1, pp. 66-70, 2000.

[8] S. Ethny, P. P. Acarnley, B. Zahawi and D. Giaouris, "Induction Machine Fault Identification Using Particle Swarm Algorithms," IEEE International Conference on Power Electronics, Drives and Energy Systems for Industrial Growth (PEDES 2006), New Delhi, India, December 2006.

[9] S. A. Ethni, B. Zahawi, D. Giaouris and P. P. Acarnley. "Comparison of Particle Swarm and Simulated Annealing Algorithms for Induction Motor Fault Identification", 7th IEEE International Conference on Industrial Informatics ( INDIN 2009), pp. 470-474, Cardiff, UK, June 2009.

[10] Ethni. S. A, Gadoue S, Zahawi B. "Induction machine winding faults identification using bacterial foraging optimization". In: 7th IET international conference on Power Electronics, Machines and Drives (PEMD). 2014, Manchester, U.K.

[11] M. Alamyal, S. M. Gadoue and B. Zahawi, "Detection of induction machine winding faults using genetic algorithm," 9th IEEE International Symposium on Diagnostics for Electric Machines, Power Electronics and Drives (SDEMPED 2013), pp.157-161, Valencia, Spain, August 2013.

[12] C. Picardi, and N. Rogano, "Parameter Identification of Induction Motor Based on Particle Swarm Optimization", in Proc. 2006 International Symposium on Power Electronics, Electrical Drives, Automation and Motion, Italy, pp. 32-37, 2006.

[13] K. M. Passino, "Biomimicry of bacterial foraging for distributed optimization and control," IEEE Control Systems Magazine, vol. 22, no. 3, pp. 52-67, 2002.

[14] M. Clerc, "Particle Swarm Optimization," ISTE, USA, 2006.

[15] IEEE Standard Test Procedure for polyphase Induction Motors and Generators. New York, USA, 2004.

[16] G. K. Singh and S. A. S. Al Kazzaz, "Induction machine drive condition monitoring and diagnostic research-a survey," Electric Power Systems Research, vol. 64, no. 2, pp. 145-158, 2003.

[17] Report of Large Motor Reliability Survey of Industrial and Commercial Installations, Part II," Industry Applications, IEEE Transactions, vol. 21, no. 4, pp. 865-872, 1985.

[18] P. F. Albrecht, J. C. Appiarius, R. M. McCoy, E. L. Owen, and D. K. Sharma, "Assessment of the Reliability of Motors in Utility Applications - Updated," Energy Conversion, IEEE Transactions, vol. 1, no. 1, pp. 39-46, 1986

[19] R. M. Tallam, S. B. Lee, G. Stone, G. B. Kliman, J. Yoo, T. G. Habetler, and R. G. Harley, "A survey of methods for detection of stator related faults in induction machines,"Diagnostics for Electric Machines, Power Electronics and Drives, IEEE International Symposium, vol. 1, pp. 35-46, Atlanta, GA, USA, 2003.

[20] R. M. Tallam, S. B. Lee, G. C. Stone, G. B. Kliman, J. Yoo, T. G. Habetler, and R. G. Harley, "A Survey of Methods for Detection of Stator-Related Faults in Induction Machines," Industry Applications, IEEE Transactions, vol. 43, no. 4, pp. 920-933, 2007. 